\title{
Responses of activities, abundances and community structures of soil denitrifiers to short-term mercury stress
}

\author{
Zhifeng Zhou ${ }^{1,2,3}$, Yuanming Zheng ${ }^{1}$, Jupei Shen ${ }^{1}$, Limei Zhang ${ }^{1}$, Yurong Liu ${ }^{1}$, Jizheng $\mathrm{He}^{1, *}$ \\ 1. State Key Laboratory of Urban and Regional Ecology, Research Center for Eco-Environmental Sciences, Chinese Academy of Sciences, \\ Beijing 100085, China.E-mail: zhouzhf@swu.edu.cn \\ 2. Graduate School of Chinese Academy of Sciences, Beijing 100039, China \\ 3. College of Resources and Environment, Southwest University, Chongqing 400716, China
}

Received 11 March 2011; revised 17 May 2011; accepted 30 May 2011

\begin{abstract}
The responses of activities, abundances and community structures of soil denitrifiers to mercury $(\mathrm{Hg})$ stress were investigated through a short-term incubation experiment. Four soil treatments with different concentrations of $\mathrm{Hg}(\mathrm{CK}, \mathrm{Hg} 25, \mathrm{Hg} 50$, and $\mathrm{Hg} 100$, denoted as 0 , 25,50 , and $100 \mathrm{mg} \mathrm{Hg} / \mathrm{kg}$ dry soil, respectively) were incubated for 28 days. Soil denitrification enzyme activity (DEA) was measured at day 3, 7 and 28. The abundances and community structures of two denitrification concerning genes, $n i r S$ ( $c d_{1}$-nitrite reductase gene) and $n o s Z$ (nitrous oxide reductase gene), were analyzed using real-time PCR and denaturing gradient gel electrophoresis (DGGE). Results showed that soil DEA was significantly stimulated in the treatments of $\mathrm{Hg} 25$ and $\mathrm{Hg} 50$ compared with others at day 7. Meanwhile, no difference in the abundances of soil nirS and nosZ was found between $\mathrm{Hg}$ spiked treatments and CK, except the lower abundance of nirS $(P<0.05)$ in the $\mathrm{Hg}$ added treatments compared with that in the $\mathrm{CK}$ at day 28 . The community structures of denitrifiers based on nirS gene presented obvious change at day 7 along with the $\mathrm{Hg}$ additions, however, no variation was found in all treatments based on the nos $\mathrm{Z}$ gene. The results indicated that $\mathrm{Hg}(\mathrm{Hg} 25$ and $\mathrm{Hg} 50)$ had a strongly short-term stimulation on soil DEA, and nirS gene is more sensitive than nos $\mathrm{Z}$ gene to $\mathrm{Hg}$ stress.
\end{abstract}

Key words: Hg; denitrification enzyme activity; nirS; nosZ; DGGE; real-time PCR

DOI: $10.1016 / \mathrm{S} 1001-0742(11) 60747-\mathrm{X}$

\section{Introduction}

Denitrification, one of the most important processes of the global nitrogen cycle, is mainly controlled by the primary soil microbial processes, in which nitrous oxide $\left(\mathrm{N}_{2} \mathrm{O}\right)$, a greenhouse gas and natural catalyst of stratospheric ozone degradation is produced. This biochemical process is driven by physiologically unrelated diverse groups of microorganisms, and through which, nitrate $\left(\mathrm{NO}_{3}{ }^{-}\right)$and nitrite $\left(\mathrm{NO}_{2}{ }^{-}\right)$are reduced to gaseous products of nitric oxide (NO), $\mathrm{N}_{2} \mathrm{O}$, and nitrogen $\left(\mathrm{N}_{2}\right)$ under suboxic conditions (Zumft, 1997; Philippot and Hojberg, 1999). To date, functional genes encoding key enzymes in denitrification, including nirS ( $c d_{1}$-nitrite reductase gene), nirK (Cu-containing nitrite reductase gene), nos $Z$ (nitrous oxide reductase gene), and nor $B$ (nitric oxide reductase gene), have been established as molecular markers in studies of the soil denitrifiers (Smith et al., 2007).

It is well known that functions of soil ecosystem are closely related to soil microorganisms, and then the responses of soil microorganisms to the stresses have been considered as indicators of soil ecosystem health (Yang

\footnotetext{
* Corresponding author. E-mail: jzhe@ @rcees.ac.cn
}

et al., 2001; Bulluck and Ristaino, 2002; Garbeva et al., 2006). By changing conformation of enzymes, inactivating essential functional groups or exchanging metal ions, heavy metals can influence the functions of soil microorganisms (Tyler, 1981). Some researchers had studied the effects of heavy metals on soil denitrification (Bollag and Barabasz, 1979; Sakadevan et al., 1999; Throbäck et al., 2007), and demonstrated the inhibition of heavy metals to denitrification. For example, Throbäck et al. (2007) described the immediate inhibitory effect of silver on soil denitrification activity by a sigmoid dose-response curve, and found novel nirK genotypes in the soil under silver stress. These studies indicated that denitrifying community responsed significantly to the stress of heavy metals and might be used as model to assess the effects of heavy metals on microorganisms in soil microcosms.

Mercury $(\mathrm{Hg})$ is one of the most toxic elements to all living organisms. Due to its persistence, bioaccumulation and toxicity, $\mathrm{Hg}$ is listed as a priority pollutant by many international agencies. China has a long history of mining and use of $\mathrm{Hg}$. During the last two decades, the consumption of $\mathrm{Hg}$ is more than 900 tons, almost $50 \%$ of worldwide production in 2000 (Jiang et al., 2006). Thus $\mathrm{Hg}$ emissions in China are widespread and the $\mathrm{Hg}$ contents 
in the atmospheres and soils in some areas are much higher than the global background values (Liu et al., 2002; Zhang et al., 2006). Qiu et al. (2004) reported that the total soil $\mathrm{Hg}$ contents ranged from 5.1 to $790 \mathrm{mg} / \mathrm{kg}$ in the mining area of Guizhou Province, Southwest of China. In the nearby paddy and upland fields, the maximum total soil $\mathrm{Hg}$ contents were up to 89 and $264 \mathrm{mg} / \mathrm{kg}$, respectively (Qiu et al., 2006). Therefore, it is worthy to study the mechanisms and responses of soil microorganisms to $\mathrm{Hg}$ stress, for the determination of $\mathrm{Hg}$ toxicity to soil microorganisms.

The effects of $\mathrm{Hg}$ on the community structures of soil bacteria in short and long-term time spans had been reported previously (Müller et al., 2001; Ranjard et al., 2006; Ruggiero et al., 2011). Recently, the responses of soil ammonia oxidizers and denitrifiers to $\mathrm{Hg}$ stress were studied by several researchers. Liu et al. (2010) found mercury inhibited the activities and changed the community compositions of soil ammonia oxidizers. Philippot et al. (2008) found $\mathrm{Hg}$ (100 $\mathrm{mg} \mathrm{Hg} / \mathrm{kg}$ soil) obviously increased the soil denitrification enzyme activity (DEA) at day 45 and changed the community structure of soil narG (periplasmic nitrate reductase gene) at day 120 during the soil incubation. Nevertheless, the relationship between soil DEA and soil denitrifiers and the responses of other functional genes involved in denitrification under $\mathrm{Hg}$ stress were less available.

In this study, through a short-term incubation experiment, the effect of gradient concentrations of $\mathrm{Hg}$ on the activity of soil denitrifiers was detected. Simultaneously, the abundances and community structures of soil nirS and nos $\mathrm{Z}$ genes under $\mathrm{Hg}$ stress were investigated. The objective was to explore the response of the denitrification activity and community compositions of soil nirS and nosZ based denitrifiers to $\mathrm{Hg}$ stress.

\section{Materials and methods}

\subsection{Microcosms and experimental design}

Topsoil $(0-20 \mathrm{~cm})$ classified as Eutyic Cambisols was collected in July 2010 from a wheat-maize rotation field located in Shunyi District of Beijing (China). The soil basic properties were $\mathrm{pH} 7.75$; organic matter $22.76 \mathrm{~g} / \mathrm{kg}$; $\mathrm{NO}_{3}{ }^{-} 21.33 \mathrm{mg} / \mathrm{kg} ; \mathrm{NH}_{4}{ }^{+} 11.28 \mathrm{mg} / \mathrm{kg} ; \mathrm{Hg} 0.02 \mathrm{mg} / \mathrm{kg}$. The soil sample was air-dried and ground to pass through a 2-mm sieve for the incubation experiment.

The effects of $\mathrm{Hg}$ on soil denitrifiers were studied using four different $\mathrm{Hg}$ treatments $(0,25,50$, and $100 \mathrm{mg} \mathrm{Hg} / \mathrm{kg}$ dry soil, represent $\mathrm{CK}, \mathrm{Hg} 25, \mathrm{Hg} 50$, and $\mathrm{Hg} 100$, respec- tively) with three replicates. The soil samples were spiked with $\mathrm{HgCl}_{2}$ solutions to give the final $\mathrm{Hg}$ concentrations of $0,25,50$, and $100 \mathrm{mg} / \mathrm{kg}$ dry soil. A total of $60 \mathrm{~g}$ each soil sample was placed in a tube ( $8 \mathrm{~cm}$ diameter, $15 \mathrm{~cm}$ height) in triplicate for each $\mathrm{Hg}$ concentration and each harvest time. In each tube, soil water content was adjusted to $35 \%$ maximum water holding capacity and was maintained throughout the experiment. Each tube was weighed weekly and sterile distilled water was added where needed. Finally, each tube was loosely covered with plastic cap allowing air-exchange and incubated in a dark incubator at $25^{\circ} \mathrm{C}$ for 28 days. Soil samples were collected from the tubes at day 3, 7 and 28 for DEA, real-time PCR and DGGE analysis.

\subsection{Measurement of soil DEA}

Each of $5 \mathrm{~g}$ fresh soil with $5 \mathrm{~mL}$ sterile distilled water was placed in a glass serum bottle and sealed with rubber septa and aluminum crimp cap. The headspace was replaced with high-purity $\mathrm{N}_{2}$ gas to achieve anaerobic condition. Approximately $15 \%(\mathrm{~V} / \mathrm{V})$ of the headspace $\mathrm{N}_{2}$ was replaced with acetylene gas $\left(\mathrm{C}_{2} \mathrm{H}_{2}\right)$. Bottles were shaken on a longitudinal shaker for $30 \mathrm{~min}$ to evenly distribute the $\mathrm{C}_{2} \mathrm{H}_{2}$ throughout the soil slurry (White and Reddy, 1999). Bottles were incubated in the dark at $25^{\circ} \mathrm{C}$ for $12 \mathrm{hr}$, and then the headspace gas samples were taken and analyzed for $\mathrm{N}_{2} \mathrm{O}$ by a gas chromatograph (GC, Model SP3410, Beijing Analytical Instrument Factory, China).

\subsection{Soil DNA extraction and real-time PCR assay}

Soil DNA was extracted from $0.5 \mathrm{~g}$ fresh soil using MoBio UltraClean ${ }^{\mathrm{TM}}$ soil DNA isolation Kits (San Diego, CA, USA) according to the manufacturer's protocol with previously described modification (He et al., 2007).

Real-time PCR was performed on an iCycler iQ5 thermocycler (Bio-Rad, USA). Amplification was performed in $25 \mu \mathrm{L}$ reaction mixtures by using $\mathrm{SYBR}^{\circledR}$ Premix Ex $\mathrm{Taq}^{\mathrm{TM}}$ as described by the suppliers (Takara Bio, Otsu, Shiga, Japan). The DNA extracts were diluted 5-fold and used as template with a final content of 1-10 $\mathrm{ng}$ in each reaction mixture. The primer sets (nirS: cd3aF/R3cd; nosZ: nosZF/nosZ1622R) listed in Table 1 were used to amplify each target gene with real-time PCR. The thermal profile used for nirS and nosZ amplification was as follows: $94^{\circ} \mathrm{C} / 2$ min; 6 cycles of $94^{\circ} \mathrm{C} / 30 \mathrm{sec}, 57^{\circ} \mathrm{C} / 30 \mathrm{sec}\left(-1^{\circ} \mathrm{C} /\right.$ cycle $)$, $72^{\circ} \mathrm{C} / 45 \mathrm{sec} ; 30$ cycles of $94^{\circ} \mathrm{C} / 30 \mathrm{sec}, 52^{\circ} \mathrm{C} / 30 \mathrm{sec}$, $72^{\circ} \mathrm{C} / 45 \mathrm{sec}$. Following the thermal profile, by measuring the fluorescence continuously as the temperature increased from 55 to $95^{\circ} \mathrm{C}$, a melting curve analysis was performed

Table 1 Primer sets used for the real-time PCR and DGGE analyses

\begin{tabular}{llll}
\hline Target gene & Primer set & Sequence $\left(5^{\prime}-3^{\prime}\right)$ & Reference \\
\hline nirS & cd3aF & GTSAACGTSAAGGARACSGG & Michotey et al., 2000 \\
& R3cd & GASTTCGGRTGSGTCTTGA & Braker and Tiedje, 2003 \\
R3cd-GC & nosZ-F & CGYTGTTCMTCGACAGCCAG & Kloos et al., 2001 \\
nosZ & nosZ1622R & CGSACCTTSTTGCCSTYGCG & Throbäck et al., 2004 \\
& nosZ1622R-GC & &
\end{tabular}

a (GGCGGCGCGCCGCCCGCCCCGCCCCCGTCGCCC) was attached to the $5^{\prime}$ end of the primers for DGGE. 
to confirm the specificity of the PCR product for each realtime PCR amplification. Data analysis was carried out with iCycler software (version 1.0.1384.0 CR). The parameter $C_{\mathrm{t}}$ (threshold cycle) was determined as the cycle number at which a statistically significant increase in the reporter fluorescence was detected.

Standard curves for real-time PCR assays were developed as described previously (He et al., 2007). Briefly, the nirS and nos $Z$ genes were PCR-amplified from extracted DNA with the primer sets (nirS: $\operatorname{cd} 3 \mathrm{aF} / \mathrm{R} 3 \mathrm{~cd}$; nosZ: nosZ-F/nosZ1622R) listed in Table 1, and then the PCR products were cloned into the pGEM-T Easy Vector (Promega Madison, USA). Plasmids used as standards for quantitative analyses were extracted from the correct insert clones of each target gene. The concentration of plasmid DNA was determined on a Nanodrop ${ }^{\circledR}$ ND-1000 UV-Vis Spectrophotometer (NanoDrop Technologies, USA). Then the copy numbers of the target genes were calculated. To generate an external standard curve, ten-fold serial dilutions of a known copy number of the plasmid DNA were subjected to real-time PCR assay in triplicate.

\subsection{PCR amplification and DGGE analysis}

For DGGE analysis, the amplification was performed in $50 \mu \mathrm{L}$ reaction mixtures including $1 \times \mathrm{PCR}$ buffer, 400 $\mu \mathrm{mol} / \mathrm{L}$ each dNTP, $2.5 \mathrm{U}$ hot star Taq DNA polymerase (Takara Bio, Otsu, Shiga, Japan) plus primers (nirS: cd3aF/R3cd-GC; nosZ: nosZ-F/nosZ1622R-GC) (Table 1). The touchdown thermal profile used for nirS amplification was as follows: $94^{\circ} \mathrm{C} / 2 \mathrm{~min} ; 10$ cycles of $94^{\circ} \mathrm{C} / 30$ sec, $57^{\circ} \mathrm{C} / 30 \sec \left(-0.5^{\circ} \mathrm{C} /\right.$ cycle $), 72^{\circ} \mathrm{C} / 45 \mathrm{sec} ; 30$ cycles of $94^{\circ} \mathrm{C} / 30 \mathrm{sec}, 52^{\circ} \mathrm{C} / 30 \mathrm{sec}, 72^{\circ} \mathrm{C} / 45 \mathrm{sec} ; 72^{\circ} \mathrm{C} / 10 \mathrm{~min}$. The thermal profile for $n o s Z$ amplification was similar to that for nirS amplification, while $58^{\circ} \mathrm{C}$ was the starting temperature for touchdown $\left(10\right.$ cycles of $-0.5^{\circ} \mathrm{C} /$ cycle $)$ and $53^{\circ} \mathrm{C}$ was the following annealing temperature.

DGGE analysis of each PCR products was performed with the DCode Universal Mutation Detection System (Bio-Rad Laboratories, Hercules, USA). PCR products of nirS and nos $Z$ genes were loaded onto $6 \%(\mathrm{~W} / \mathrm{V})$ polyacrylamide (37.5:1, acrylamide:bisacrylamide) gels with a denaturing gradient of $50 \%-75 \%$ and $50 \%-70 \%$ (100\% denaturant contains $7 \mathrm{~mol} / \mathrm{L}$ urea and $40 \%(\mathrm{~V} / \mathrm{V})$ formamide), respectively. Electrophoreses were run at $60^{\circ} \mathrm{C}$ and $100 \mathrm{~V}$ for $15 \mathrm{hr}$ for nirS and $13 \mathrm{hr}$ for nosZ. The gels were stained for $30 \mathrm{~min}$ according to the manufacturer's instructions (Invitrogen 20 Molecular Probes, Eugene, USA), scanned by a GBOX/HR-E-M (Gene Company Limited, Syngene, UK). The obtained results were analyzed using Quantity One Software 4.5.2 (Bio-Rad Laboratories, Hercules, USA) and UPGMA algorithms were used to cluster the DGGE patterns.

\subsection{Data analysis}

One-way analysis of variance (ANOVA) followed by SN-K-test was performed using SPSS 11.5 (SPSS Inc., Chicago, USA) to check for quantitative differences between samples. $P<0.05$ was considered to be statistically significant.

\section{Results}

\subsection{Effect of $\mathrm{Hg}$ on the soil denitrification enzyme activity (DEA)}

The effects of $\mathrm{Hg}$ on the soil DEA are shown in Fig. 1. At the beginning of the incubation (day 3), the lowest DEA were detected in the $\mathrm{Hg} 100$, followed by the $\mathrm{Hg} 25$ treatment. No significant difference was found between $\mathrm{CK}$ and Hg50 treatment. But at day 7, the DEA in the $\mathrm{Hg} 50$ and $\mathrm{Hg} 25$ were almost two times higher than that in $\mathrm{CK}$, while no difference was found between $\mathrm{CK}$ and Hg100 treatment. At the end of the incubation (day 28), $\mathrm{Hg} 100$ had a significantly higher DEA than CK, and no difference was found between $\mathrm{CK}$ and the other two $\mathrm{Hg}$ addition treatments.

\subsection{Effects of $\mathrm{Hg}$ on the abundances of soil nirS and nos $Z$ genes}

The abundances of soil nirS and nosZ genes in the treatments with different $\mathrm{Hg}$ additions are shown in Fig. 2. At day 3 and 7, the abundances of soil nirS gene had no difference between $\mathrm{CK}$ and the other $\mathrm{Hg}$ addition treatments. While at the end (day 28) of the incubation, the nirS abundance in the CK was obviously higher than those in all the $\mathrm{Hg}$ treatments (Fig. 2a). As to the abundance of soil nos $Z$ gene, no significant difference was found among all the treatments during the incubation (Fig. 2b).

\subsection{Effects of $\mathrm{Hg}$ on the community structures of soil nirS and nos $Z$ genes}

At day 7 and 28, the community structures of nirS and nos $Z$ genes were analyzed by DGGE (Figs. 3a and 4a) and the DGGE profiles with three replicates for each treatment indicated good reproducibility.

The nirS DGGE profiles showed obvious variations between $\mathrm{CK}$ and all $\mathrm{Hg}$ addition treatments at day 7 , as some bands in the dotted line rectangles only clearly existed in the $\mathrm{Hg}$ addition treatments, while the variations disappeared at day 28 (Fig. 3a). The UPGMA cluster analysis based on the DGGE patterns also showed that nirS

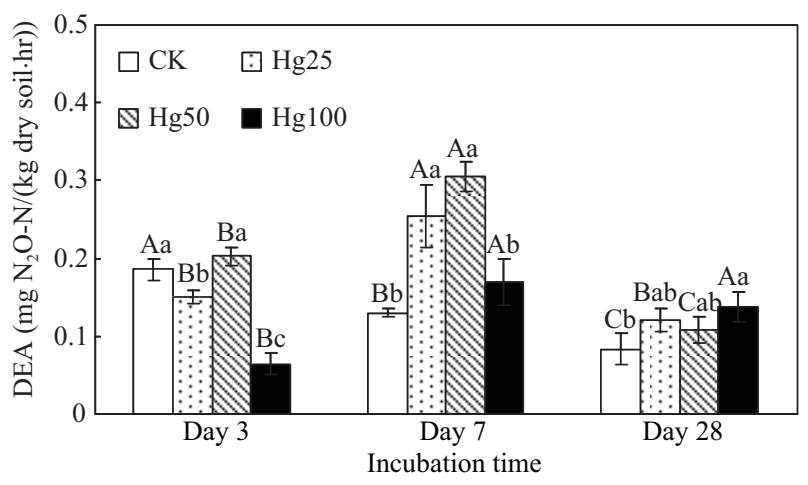

Fig. 1 Soil denitrification enzyme activity (DEA) in the treatments with different concentrations of $\mathrm{Hg}$ (CK, $\mathrm{Hg} 25, \mathrm{Hg} 50$, and $\mathrm{Hg} 100$, represent $0,25,50$, and $100 \mathrm{mg} \mathrm{Hg} / \mathrm{kg}$ dry soil, respectively) during the incubation. Error bars indicate standard deviations $(n=3)$. The different uppercase and lowercase letters above bars indicate significant differences $(P<$ 0.05 ) among the same treatment at day 3,7 and 28 and all the treatments at the same sampling days, respectively. 


\section{$\square \mathrm{CK} \quad \square \mathrm{Hg} 25 \quad \mathrm{NH} 50 \quad \mathbf{H g} 100$}
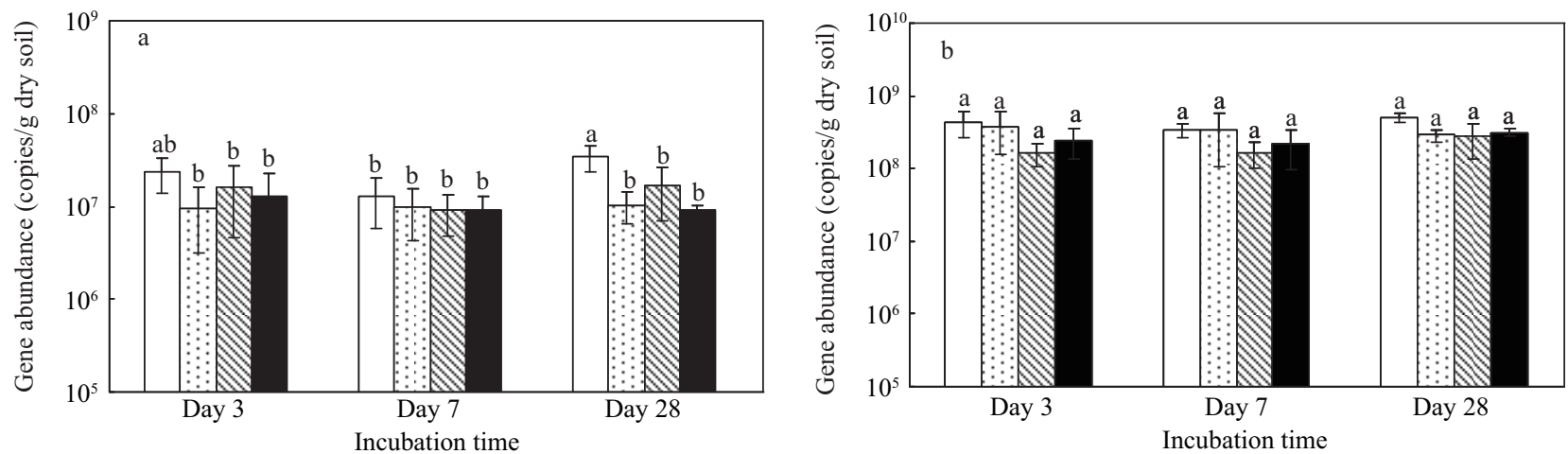

Fig. 2 Quantification of soil nirS gene (a) and nos Z gene (b) copy numbers in the treatments with different concentrations of Hg during the incubation. Error bars indicate standard deviations $(n=3)$. The different letters above bars indicate significant differences $(P<0.05)$ among treatments during the incubation.

community structures in all $\mathrm{Hg}$ addition treatments had relatively similar structures at day 7 , which were obviously different from those in $\mathrm{CK}$ at day 7 and all the treatments at day 28 (Fig. 3b).
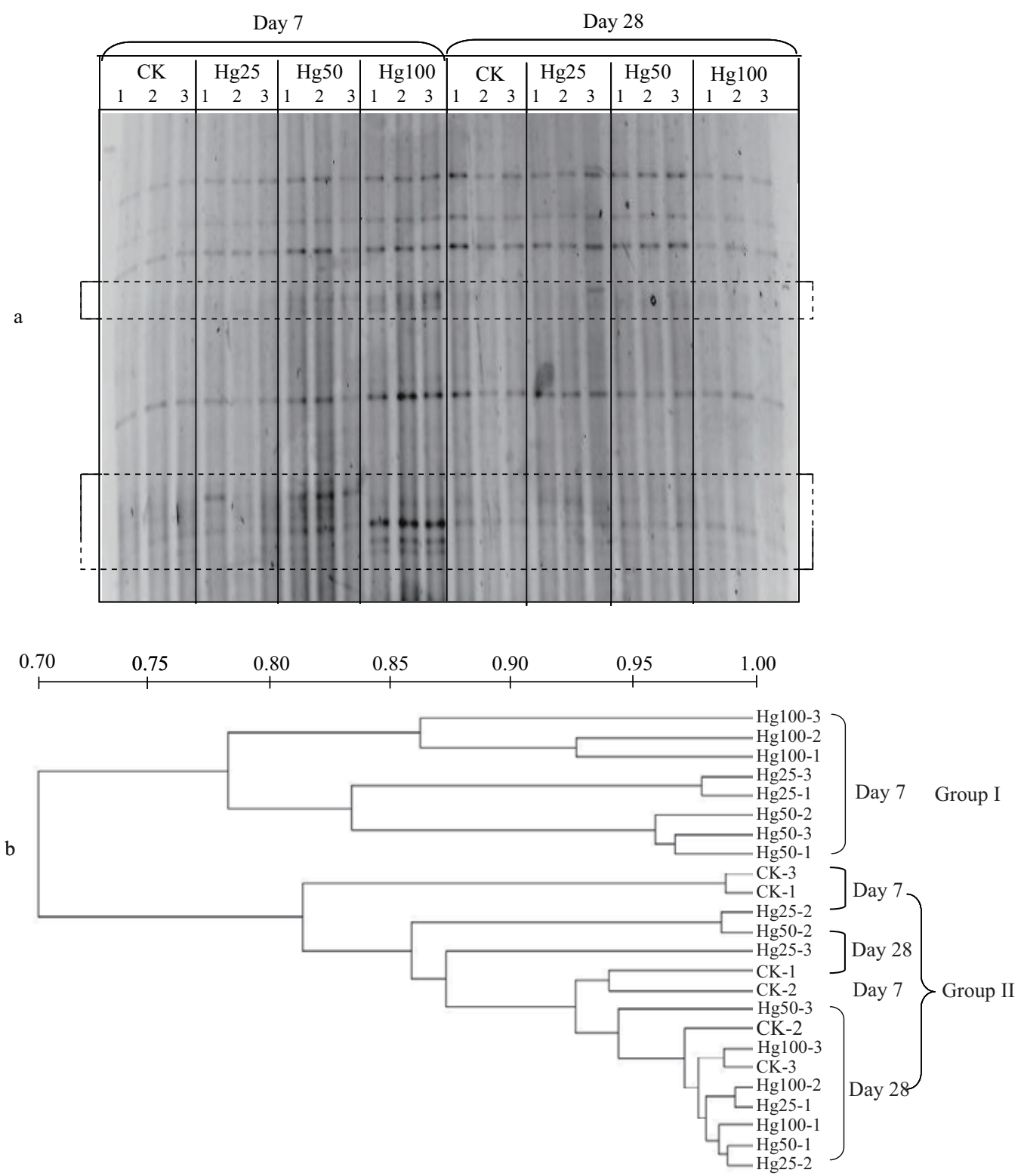

Fig. 3 (a) DGGE profiles of soil nirS gene amplified from the treatments with different concentrations of $\mathrm{Hg}$ at day 7 and 28 . The districts in the rectangles with dotted line showed the special bands in the $\mathrm{Hg}$ treatments at day 7; (b) cluster analysis of nirS gene communities generated by the nirS DGGE banding patterns. 

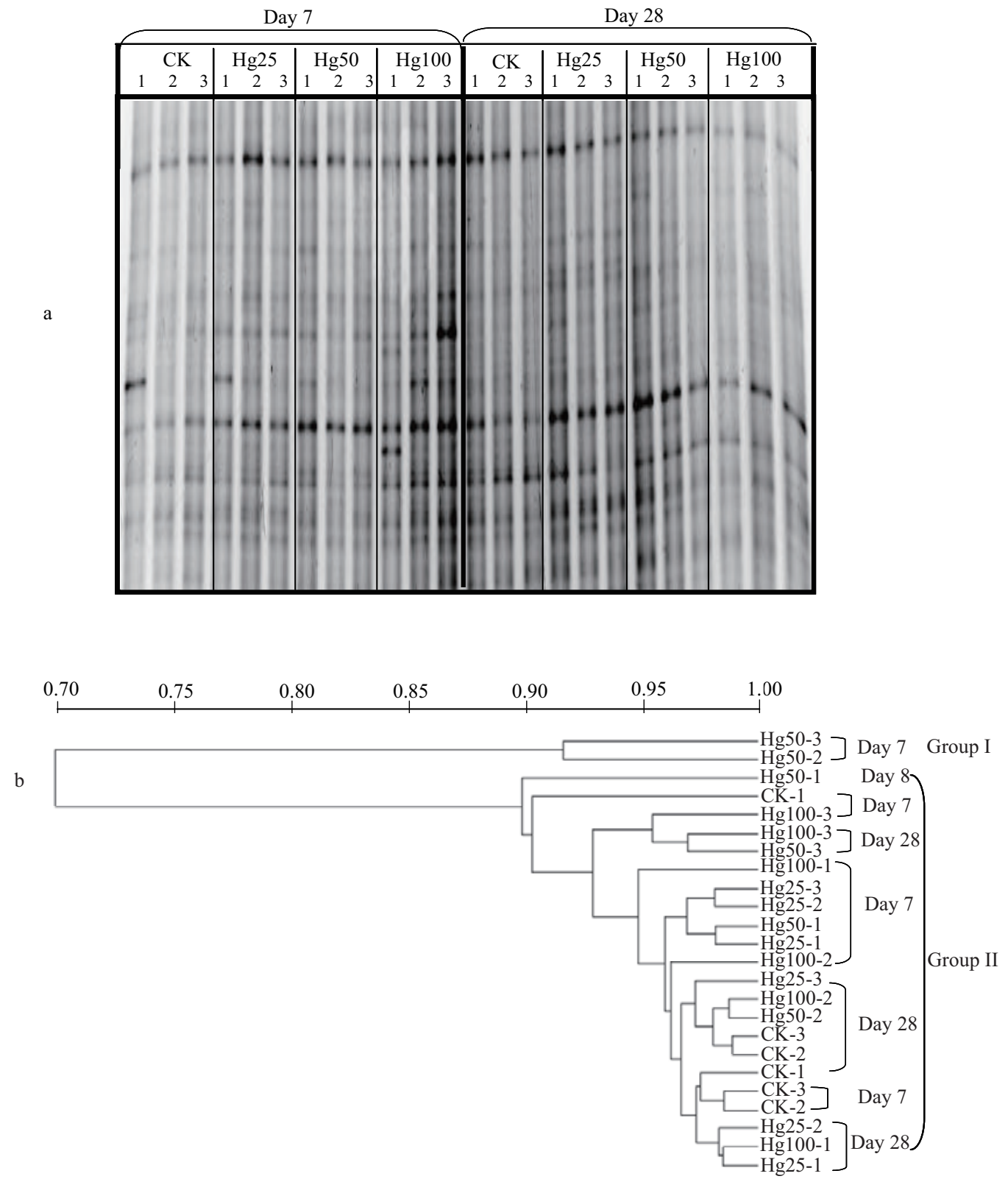

Fig. 4 (a) DGGE profiles of soil nosZ gene amplified from the treatments with different concentrations of $\mathrm{Hg}$ at day 7 and 28 ; (b) cluster analysis of nos $Z$ gene communities generated by the nos $Z$ DGGE banding patterns.

The nosZ DGGE profiles showed minor variations among all the treatments at day 7 and 28 (Fig. 4a), and the UPGMA cluster analysis of the nosZ DGGE patterns also indicated that nos $Z$ gene community structures had no obvious differences among these treatments (Fig. $4 \mathrm{~b}$ ).

\section{Discussion}

\subsection{Effect of Hg on soil DEA}

In this study, the soil DEA was obviously inhibited by the highest $\mathrm{Hg}$ concentration treatment $(\mathrm{Hg} 100)$ at day 3 , and then recovered at day 7. The other two lower $\mathrm{Hg}$ additions (Hg25 and Hg50) sharply stimulated the soil DEA compared with CK at day 7, and had no obvious effect on the soil DEA at the end of the incubation (Fig. 1). The rapid inhibition of the highest $\mathrm{Hg}$ concentration on the soil DEA indicated the toxicity of $\mathrm{Hg}$ to the activity of soil denitri- fying microorganisms, while the following increased DEA confirmed the resilience of soil microorganisms under $\mathrm{Hg}$ stress. The inhibiting effect of heavy metals to soil DEA had been reported proviously (Holtan-Hartwig et al., 2002; Magalhães et al., 2007; Ruyters et al., 2010). The significantly higher soil EDA in the $\mathrm{Hg} 25$ and $\mathrm{Hg} 50$ treatments was in accord with the result of Philippot et al. (2008), who found that $\mathrm{Hg}(100 \mathrm{mg} \mathrm{Hg} / \mathrm{kg}$ ) resulted in a three to fourfold increase of soil DEA within 2 weeks compared with $\mathrm{CK}$ (without $\mathrm{Hg}$ addition). The stimulation of $\mathrm{Hg}$ on soil DEA could attribute to the increased organic matter due to the lysis of microorganisms under the toxicity of $\mathrm{Hg}$ (Philippot et al., 2008). In fact, the wide distribution of soil denitrifiers could not be ignored, because some $\mathrm{Hg}$ resistant bacteria might have the denitrification ability. For example, Kesseru et al. (2002) found Ochrobactrum anthropi, a well known denitrifier, was tolerant to $\mathrm{Hg}$ and lead (Pb). Chiu et al. (2007) isolated two Hg-resistant bacterial 
strains with capacity of denitrification from a Taiwanese estuary. Therefore, the soil Hg-resistant bacterial harboring denitrification ability could be dominant and promote the soil DEA with the increased available substrates under $\mathrm{Hg}$ stress. The mechanism of the stimulation of $\mathrm{Hg}$ on soil DEA was still unclear, and it might be a combined action of complex soil biological and chemical processes under $\mathrm{Hg}$ stress.

\subsection{Effects of $\mathrm{Hg}$ on the abundances and community structures of soil nirS and nosZ genes}

The results of DGGE profiles indicated that nirS based denitrifier responded more sensitively than nos $Z$ based denitrifier to the $\mathrm{Hg}$ stress, which was in a good agreement with previous findings that different denitrification concerning genes responded differently to environmental stresses (Hai et al., 2009; Yoshida et al., 2010). The stability of soil nos $Z$ gene was also confirmed by Ruyters et al. (2010), who found minor changes in soil nos $Z$ community structure under zinc stress. Furthermore, the result of obviously increased diversity in nirS gene under the $\mathrm{Hg}$ stress at day 7 was in accord with the result of Throbäck et al. (2007), who found that the diversity of the other nitrite reductase gene ( $\mathrm{Cu}$-nitrite reductase gene, $n i r K$ ) obviously increased under silver stress. Therefore, our results here illustrated that some $\mathrm{Hg}$-resistant bacterial harboring denitrification genes in soil were selected under $\mathrm{Hg}$ stress, and changed from minor into major populations enough to be detected by DGGE.

\subsection{Relationship between soil DEA and soil denitrifiers under Hg stress}

The DEA in $\mathrm{Hg} 25$ and $\mathrm{Hg} 50$ obviously increased, compared with that in $\mathrm{CK}$ at day 7, but no difference in the abundances of soil nirS and nosZ genes was found between these two $\mathrm{Hg}$ addition treatments and $\mathrm{CK}$ at the same sampling day. This result indicated that the soil DEA might have no direct relationship with the abundances of soil nirS or nos $Z$ gene. By contrast, the obvious variation in nirS community structure was corresponding to the significantly higher DEA in the $\mathrm{Hg} 25$ and $\mathrm{Hg} 50$ treatments at day 7. These results indicated that the community structures, but not the abundance controlled the soil DEA. There are always some arguments about the relationship between the abundances and community structures of denitrifiers and the soil denitrification activity. Rich et al. (2003) found a strong relationship between the community composition of denitrifiers and DEA in two soils. However, Boyle et al. (2006) found no relationship between the denitrifier community composition and denitrification activity. Our result illustrated that there was obvious relationship between the structures of denitrifiers and soil denitrification activity under $\mathrm{Hg}$ stress.

\section{Conclusions}

In conclusion, our results demonstrated that $\mathrm{Hg}$ could influence the activity and community composition of soil denitrifiers. The highest $(\mathrm{Hg} 100)$ and lower $(\mathrm{Hg} 25, \mathrm{Hg} 50)$ concentrations of $\mathrm{Hg}$ had a rapid inhibition and short-term stimulation on the soil DEA, respectively. Furthermore, the soil nirS gene responded more sensitively than nos $Z$ gene to the $\mathrm{Hg}$ stress, and only the community structure of nirS gene revealed a direct relationship with the soil DEA. To clarify the effect of heavy metals on soil denitrifiers, some mRNA depended and in situ methods should be applied in this field, and the long-term effects of heavy metals on soil denitrifiers should be another important aspect in the future.

\section{Acknowledgments}

This work was supported by the Natural Science Foundation of China (No. 41020114001, 50921064), the Ministry of Sciences and Technology (No. 2009AA06Z402, 2008ZX07209-006-04) and the CAS/SAFEA International Partnership Program for Creative Research Teams of "Ecosystem Processes and Services".

\section{References}

Bollag J M, Barabasz W, 1979. Effect of heavy metals on the denitrification process in soil. Journal of Environmental Quality, 8(2): 196-201.

Boyle S A, Rich J J, Bottomley P J, Cromack K Jr, Myrold D D, 2006. Reciprocal transfer effects on denitrifying community composition and activity at forest and meadow sites in the Cascade Mountains of Oregon. Soil Biology and Biochemistry, 38(5): 870-878.

Braker G, Tiedje J M, 2003. Nitric oxide reductase (norB) genes from pure cultures and environmental samples. Applied and Environmental Microbiology, 69(6): 3476-3483.

Bulluck L R, Ristaino J B, 2002. Effect of synthetic and organic soil fertility amendments on southern blight, soil microbial communities, and yield of processing tomatoes. Phytopathology, 92(2): 181-189.

Chiu H H, Shieh W Y, Lin S Y, Tseng C M, Chiang P W, Wagner-Döbler I, 2007. Alteromonas tagae sp. nov. and Alteromonas simiduii sp. nov., mercury-resistant bacteria isolated from a Taiwanese estuary. International Journal of Systematic and Evolutionary Microbiology, 57(6): 12091216.

Garbeva P, Postma J, Van Veen J A, Van Elsas J D, 2006. Effect of above-ground plant species on soil microbial community structure and its impact on suppression of Rhizoctonia solani AG3. Environmental Microbiology, 8(2): 233-246.

Hai B, Diallo N H, Sall S, Haesler F, Schauss K, Bonzi M et al., 2009. Quantification of key genes steering the microbial nitrogen cycle in the rhizosphere of sorghum cultivars in tropical agroecosystems. Applied and Environmental Microbiology, 75(15): 4993-5000.

He J Z, Shen J P, Zhang L M, Zhu Y G, Zheng Y M, Xu M G et al., 2007. Quantitative analyses of the abundance and composition of ammonia-oxidizing bacteria and ammonia-oxidizing archaea of a Chinese upland red soil under long-term fertilization practices. Environmental Microbiology, 9(9): 2364-2374.

Holtan-Hartwig L, Bechmann M, Hoyas T R, Linjordet R, Bakken L R, 2002. Heavy metals tolerance of soil denitrifying communities: $\mathrm{N}_{2} \mathrm{O}$ dynamics. Soil Biology and Biochemistry, 34(8): 1181-1190. 
Jiang G B, Shi J B, Feng X B, 2006. Mercury pollution in China. Environmental Science and Technology, 40(12): 3672-3678.

Kesseru P, Kiss I, Bihari Z, Polyák B, 2002. The effects of $\mathrm{NaCl}$ and some heavy metals on the denitrification activity of Ochrobactrum anthropi. Journal of Basic Microbiology, 42(4): 268-276.

Kloos K, Mergel A, Rosch C, Bothe H, 2001. Denitrification within the genus Azospirillum and other associative bacteria. Australian Journal of Plant Physiology, 28(9): 991-998.

Liu S L, Nadim F, Perkins C, Carley R J, Hoag G E, Lin Y H et al., 2002. Atmospheric mercury monitoring survey in Beijing, China. Chemosphere, 48(1): 97-107.

Liu Y R, Zheng Y M, Shen J P, Zhang L M, He J Z, 2010. Effects of mercury on the activity and community composition of soil ammonia oxidizers. Environmental Science and Pollution Research, 17(6): 1237-1244.

Magalhães C, Costa J, Teixeira C, Bordalo A A, 2007. Impact of trace metals on denitrification in estuarine sediments of the Douro River estuary, Portugal. Marine Chemistry, 107(3): 332-341.

Michotey V, Méjean V, Bonin P, 2000. Comparison of methods for quantification of cytochrome $c d_{1}$-denitrifying bacteria in environmental marine samples. Applied and Environmental Microbiology, 66(4): 1564-1571.

Müller A K, Westergaard K, Christensen S, Sørensen S J, 2001. The effect of long-term mercury pollution on the soil microbial community. FEMS Microbiology Ecology, 36(1): 11-19.

Philippot L, Cregut M, Chèneby D, Bressan M, Dequiet S, Martin-Laurent F et al., 2008. Effect of primary mild stresses on resilience and resistance of the nitrate reducer community to a subsequent severe stress. FEMS Microbiology Letters, 285(1): 51-57.

Philippot L, Hojberg O, 1999. Dissimilatory nitrate reductases in bacteria. Biochimica Et Biophysica Acta-Gene Structure and Expression, 1446(1-2): 1-23.

Qiu G L, Feng X B, Wang S F, Shang L H, 2004. Mercury and methylmercury in riparian soil, sediments, mine-waste calcines, and moss from abandoned $\mathrm{Hg}$ mines in east Guizhou Province, southwestern China. Applied Geochemistry, 20(3): 627-638.

Qiu G L, Feng X B, Wang S F, Shang L H, 2006. Total mercury and methylmercury in soils collected from Guizhou Hgmined areas. Environmental Science, 27(3): 550-555.

Ranjard L, Lignier L, Chaussod R, 2006. Cumulative effects of short-term polymetal contamination on soil bacterial community structure. Applied and Environmental Microbiology, 72(2): 1684-1687.
Rich J J, Heichen R S, Bottomley P J, Cromack K Jr, Myrold D D, 2003. Community composition and functioning of denitrifying bacteria from adjacent meadow and forest soils. Applied and Environmental Microbiology, 69(10): 59745982.

Ruggiero P, Terzano R, Spagnuolo M, Cavalca L, Colombo M, Andreoni V et al., 2011. Hg bioavailability and impact on bacterial communities in a long-term polluted soil. Journal of Environmental Monitoring, 13(1): 145-156.

Ruyters S, Mertens J, T'Seyen I, Springael D, Smolders E, 2010. Dynamics of the nitrous oxide reducing community during adaptation to $\mathrm{Zn}$ stress in soil. Soil Biology and Biochemistry, 42(9): 1581-1587.

Sakadevan K, Zheng H, Bavor H J, 1999. Impact of heavy metals on denitrification in surface wetland sediments receiving wastewater. Water Science and Technology, 40(3): 349-355.

Smith C J, Nedwell D B, Dong L F, Osborn A M, 2007. Diversity and abundance of nitrate reductase genes (narG and napA), nitrite reductase genes (nirS and $n r f A$ ), and their transcripts in estuarine sediments. Applied and Environmental Microbiology, 73(11): 3612-3622.

Throbäck I N, Enwall K, Jarvis A, Hallin S, 2004. Reassessing PCR primers targeting nirS, nirK and nosZ genes for community surveys of denitrifying bacteria with DGGE. FEMS Microbiology Ecology, 49(3): 401-417.

Throbäck I N, Johansson M, Rosenquist M, Pell M, Hansson $\mathrm{M}$, Hallin S, 2007. Silver $\left(\mathrm{Ag}^{+}\right)$reduces denitrification and induces enrichment of novel nirK genotypes in soil. FEMS Microbiology Letters, 270(2): 189-194.

Tyler G, 1981. Heavy metals in soil biology and biochemistry. In: Soil Biochemistry (Paul E A, Ladd J N, eds.). Marcel Dekker, New York. 371-414.

White J R, Reddy K R, 1999. Influence of nitrate and phosphorus loading on denitrifying enzyme activity in Everglades wetland soils. Soil Science Society of American, 63(6): 1945-1954.

Yang C H, Crowley D E, Menge J A, 2001. 16S rDNA fingerprinting of rhizosphere bacterial communities associated with healthy and phytophthora infected avocado roots. FEMS Microbiology Ecology, 35(2): 129-136.

Yoshida M, Ishii S, Otsuka S, Senoo K, 2010. nirK-harboring denitrifiers are more responsive to denitrification-inducing conditions in rice paddy soil than nirS-harboring bacteria. Microbes and Environments, 25(1): 45-48.

Zhang X M, Luo K L, Sun X Z, Tan J A, Lu Y L, 2006. Mercury in the topsoil and dust of Beijing City. Science of the Total Environment, 368(2-3): 713-722.

Zumft W G, 1997. Cell biology and molecular basis of denitrification. Microbiology and Molecular Biology Reviews, 61(4): 533-616. 